\title{
Withdrawal effect of Chlorpromazine and Diazepam on chick blood (Plasma, Red Blood Cell) Acetyl cholinesterase activity
}

\author{
Luaay K. Yacoub \\ Department of Basic Science, College of Dentistry, \\ University of Mosul
}

Received

$5 / 3 / 2006$
Accepted

$10 / 5 / 2006$

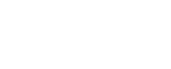

ادى تجريع أرراخ الججاج بالكلوربرومازين( 50 ملغم/كغ م/يد -وم)وال ـدليازيبلم( 30

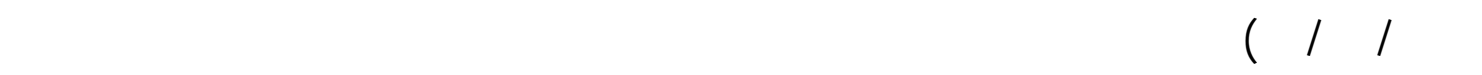

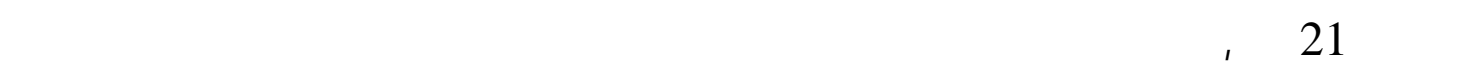
الهم وكريك الهم الحمر وبواقع 43 \% و 63 \% وعلى نحومتعاقب فى المجموعة المعلملة

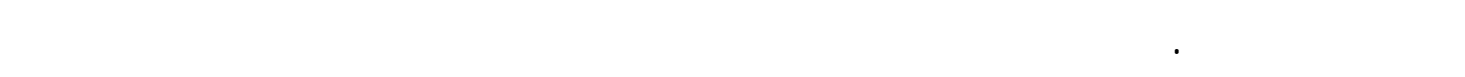

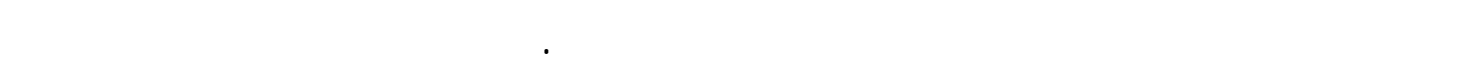

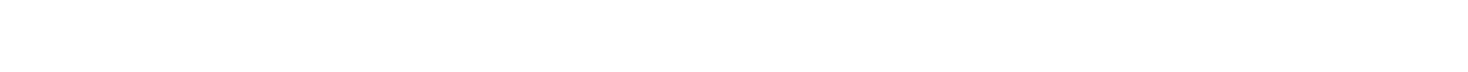

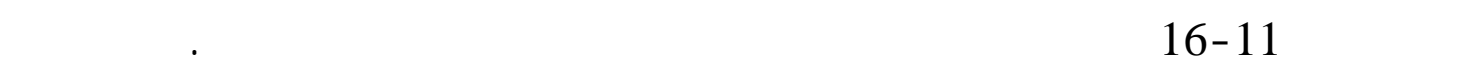
النتائج التائير الرلجع (العكسه)لكل من الكلوربرومازين والدايازيبلم فى نشط النزيم الإس تيل كولين لمتريز فى هم افراخ الدجاج.

\section{Abstract}

Administration of chlorpromazine at ( $50 \mathrm{mg} / \mathrm{kg} /$ day ) orally for a period of 21 days resulted in a significant increase in chick blood plasma and RBC acetyl cholinesterase activity by $43 \%$ and $63 \%$ respectively , where as only a slight and non significant increase was observed when diazepam was given at ( $30 \mathrm{mg} / \mathrm{kg} /$ day ) orally in comparison with control group . However once The drugs were been discontinued, the enzyme activity returned to pretreatment level in about 11-16 days in group received chlorpromazine, suggesting that the drugs effect is reversible. 


\section{Introduction}

Acetyl cholinesterase (AChE) is a membrane bound enzyme found in different tissues and play a important role for regulation of most physiological event, involving the turnover of acetylcholine (1-3). The activity of blood and/or 'true' AChE have been found to be affected by a number of antipsychotic drugs(1,4-9).Chronic treatment of rat and/or chicks with chlorpromazine and diazepam resulted increase in AChE activity(4,5). Similar finding were obtained from enzyme assay of chick and rabbit brain and cerebrospinal fluid (10).The effect by chlorpromazine in true AChE activity appear to be reversible (1), depending on the duration of drug administration (11). The aim of the present study is to examine the probability of reversible effect of chlorpromazine and diazepam on red blood cell 'true'AChE and plasma'pseudo'AChE activity in chicks.

\section{Materials and Methods}

Thirty- six chicks $2-2.5$ months old and weighing $300-350$ g were used .They were housed under standard condition of temperature ( $27 \mathrm{C}$ ), and had free access to food ( Commercial chick ration , Nebrese Co ., Mosul, Iraq . ) and water. The birds were divided into four groups of 9 chicks each. One animal in each group served as control chicks were administration orally with $1 \mathrm{ml} / \mathrm{kg}$ body weight physiological saline, The remaining animal in each group are sub-divided in to two group (4-each group) were administration chlorpromazine (May and Baker Co., England) at $50 \mathrm{mg} / \mathrm{kg} /$ day orally and diazepam (Arab Pharmaceutical Manufacturing Co., Jordan) at $30 \mathrm{mg} / \mathrm{kg} /$ day orally. The volume of administration of both drugs was $1 \mathrm{ml} / \mathrm{kg}$ body weight, and administration were made in 24-h interval for a period of 21 days, and the drugs was then withdrawn. At the end of experiment, chicks were sacrificed after ether anesthesia on days 1,6,11 and 16 after cessation of the drugs administration and blood was rapidly collected. Blood samples were deranged by using treated heparinized syringe (Braun, Germany) and separated plasma from RBC by centrifugation in (3000 rpm) for 10 min. Samples of blood stored in -20 C until the time of estimation of the enzyme activity ( $7-10$ days ) $.0 .2 \mathrm{ml}$ from plasma and red blood cell samples was used for AChE activity measurement using acetylthiocholine iodide ( $7.5 \%$ ) ( Fluka , Switzer land ) ( 12 ). All assays were done in duplicate. The statistical significance of the differences between mean values was analyzed by students't ' test (13). The level of significance was at $\mathrm{p}<0.01$. 


\section{Results and Discussion}

Table- 1 shows the enzyme activity in chick blood at different time interval after withdrawal of the chlorpromazine and diazepam administration. It is evident from the results that the enzyme activity were increased at a significant level in both blood plasma and red blood cell by $43 \%$ and $63 \%$ respectively in group received chlorpromazine , and only $10 \%$ and $13 \%$ respectively in group received diazepam on day 22.i.e. one day after withdrawal of the drugs. However, restoration of the normal level (pretreatment level) of the enzyme activity has been obtained at certain time interval. We have reported recently that chlorpromazine and diazepam increased true AChE activity in chick (5). In the present study, we found that the enzyme activity when increased by chlorpromazine and diazepam returned to the pretreatment level 11-16 days after withdrawal of the drugs as compared with the control group table- 1 . The effect seemed to be due to changes in membrane-associated properties $(4,7,8)$. Any drugs which alter the composition of the cell microsomal membrane would also affect the enzyme-bounded activity $(1,4,7,8)$. Chlorpromazine can easily accumulated inside the membrane vesicle (7, $14)$, alter membrane permeability and fluidity $(4,7,8,15)$. In our study, we believe that the changes of the enzyme activity in the former time is possibly due to inhibited turnover of acetylcholine, and diminished the adaptive effect in the enzyme for acetylcholine synthesis and degradation. The non significant effect of diazepam on true AChE activity is accepted with other reports $(4,16)$. The data presented here suggest that the increase of blood 'true' plasma and red cell acetylcholinesterase activity by chlorpromazine and diazepam is reversible. 



\section{Table 1: AChE activity in chick blood (plasma, red blood cell) after withdrawal of chlorpromazine and diazepam.}

\begin{tabular}{|c|c|c|c|c|c|c|c|c|c|}
\hline \multirow[b]{3}{*}{$\begin{array}{c}\text { Days } \\
\text { after } \\
\text { withdra } \\
\text { wal }\end{array}$} & \multirow[b]{3}{*}{$\begin{array}{l}\text { Normal saline } \\
\text { (control) }\end{array}$} & \multirow{2}{*}{\multicolumn{4}{|c|}{$\begin{array}{c}\Delta \mathrm{pH} / 30 \mathrm{~min} \\
\text { Chlorpromazine } 50 \mathrm{mg} / \mathrm{kg}\end{array}$}} & & & & \\
\hline & & & & & & \multicolumn{4}{|c|}{ Diazepam 30 mg / kg } \\
\hline & & Plasma & $\begin{array}{c}\% \\
\text { increase }\end{array}$ & Red blood cell & $\begin{array}{c}\% \\
\text { increase }\end{array}$ & Plasma & $\begin{array}{c}\% \\
\text { increase }\end{array}$ & Red blood cell & $\%$ increase \\
\hline 1 & $\mathbf{0 . 3 0} \pm \mathbf{0 . 0 1}$ & $0.43 \pm 0.02$ & $43 \%$ & $0.49 \pm 0.02$ & $63 \%$ & $\pm 0.02^{0.33}$ & $10 \%$ & $0.34 \pm 0.02$ & $13 \%$ \\
\hline 6 & $0.29 \pm 0.02$ & $0.39 \pm 0.03$ & $36 \%$ & $0.42 \pm 0.01$ & $45 \%$ & $0.31 \pm 0.01$ & $7 \%$ & $0.32 \pm 0.02$ & $10 \%$ \\
\hline 11 & $0.29 \pm 0.02$ & $0.31 \pm 0.01$ & $7 \%$ & $0.32 \pm 0.02$ & $10 \%$ & $\mathbf{0 . 3 0} \pm \mathbf{0 . 0 1}$ & $3.4 \%$ & $0.30 \pm 0.01$ & $3.4 \%$ \\
\hline 16 & $0.30 \pm 0.02$ & $\mathbf{0 . 3 0} \pm \mathbf{0 . 0 3}$ & $0.3 \%$ & $\mathbf{0 . 3 0} \pm \mathbf{0 . 0 1}$ & $1.6 \%$ & \pm 0.02 & $0.2 \%$ & \pm 0.02 & $0.3 \%$ \\
\hline
\end{tabular}

The animal were administration with chlorpromazine and diazepam orally each day for 21 days .The set of animal were sacrificed on the day 22 .i.e. day one after the drugs was discontinued and then every 5 days. The result shown with the treated animals were mean $\pm S$. E. of the mean from four animals $(n=4)$ at $* p<0.01$ from the control value . 



\section{REFRENCES}

1. Mazumder B, Mokherjee S and Sen P C, Molecular.Cell.Biochem., 95, 13-20(1990).

2. Adhikary J G, Nandy P, Chandra S, Sikder R and Sen P C, Biochem. Int., 25, 5,951-961 (1991).

3. Cohen B M and Zubenko G S, Psychopharmacol. 86, 365368(1985).

4. Oner B S and Eryurek F G, Neuro. Psychopharmacol and Biol.Psychiat. 18, 555-562(1994).

5. Yakoub L K, J.Edu. Sci., 37, 13-18 (1999).

6. Banerjee J, Ghosh P, Mitra S, Ghosh N and Bhattacharya S, J. oxicol. Environm. Health. 33, 283-290(1991).

7. Spinedi A , Pacini L, Limatola C, Luly P, Farias R N, J. Biochem., 278,2,461-465(1991).

8. Ahyayauch H, Goni F M, Bennouna M, J. Liposome. Res., 13, 2,147-155(2003).

9. Muller T C, Rocha J B, Mersch U M, Neis R T, Schetinger M R, Biochem. Biophys. Acta. 21, 1587, 92-98 (2002).

10.Greenfield S A, Ghabb I W and Smith A D, Neuropharmacol. 18, 127-132(1989).

11. Mahadik S P, Laen H, Korenovsky A and Karpiak S E, Biol.Psychiatry., 24, 199-217(1988).

12. Mohammad F K and St Omer V E V, Minire view. Vet. Hum. Toxicol. 24, 119-121 (1982).

13.Burning J L and Kintz B L, Glenview, IL. Foremen and Co., 18 (1975).

14.Bally M D ,Hoppe M J , Echteld C J and Cullis P R ,Biovhem.Biophys.Acta.,812,66-76(1985).

15.Spirtes M A and Guth P S ,Biochem.Pharmacol., 12, 37-46(1993).

16.Shin T M, Brain. Res. Bull., 26, 4, 565-573 (1991). 